\title{
New records, potential distribution, and conservation of the Near Threatened cave bat Natalus macrourus in Brazil
}

\author{
Mariana Delgado-Jaramillo, Eder Barbier and Enrico Bernard
}

\begin{abstract}
Species with specific roosting, foraging or breeding requirements are particularly vulnerable to habitat loss and degradation. For bats, the availability and environmental condition of caves can be a limiting factor. The cave specialist Natalus macrourus (formerly Natalus espiritosantensis) is categorized as Near Threatened on the IUCN Red List but as Vulnerable in Brazil, based on a projected population reduction and a decline in its area of occupancy, extent of occurrence and/or quality of habitat. There is a lack of knowledge about the species' distribution, natural history and ecology, information that is required for conservation. Using new occurrence data and potential distribution modelling we evaluated the distribution of $N$. macrourus in Brazil, analysed pressures on and threats to the species, and assessed the species' conservation needs. Natalus macrourus is positively associated with areas with higher probability of cave occurrence and negatively associated with areas of high variation in mean daily temperature and mean annual rainfall. Areas with high environmental suitability for N. macrourus correspond to only $3 \%$ of the potential distribution modelled. We estimate that the species has already lost $54 \%$ of its natural habitat and that there is $<35 \%$ of habitat remaining in areas with high environmental suitability. We calculated that approximately half of the caves in areas with high environmental suitability are $<5 \mathrm{~km}$ from mining operations and only $4 \%$ of the species' potential distribution lies within protected areas. Given the strong association of $N$. macrourus with caves, it is important to protect these habitats, and we recommend that caves where the species is present should receive immediate protection.
\end{abstract}

Keywords Caatinga, caves, Chiroptera, MaxEnt, Natalidae, Natalus macrourus, species distribution modelling, threatened species

\footnotetext{
Mariana Delgado-Jaramillo*, Eder Barbier* and Enrico Bernard (Corresponding author) Laboratório de Ciência Aplicada à Conservação da Biodiversidade, Departamento de Zoologia, Universidade Federal de Pernambuco, Rua Nelson Chaves $\mathrm{s} / \mathrm{n}$, Cidade Universitária, Recife, Pernambuco 50670-901, Brazil. E-mail enrico.bernard@ufpe.br

*Also at: Programa de Pós-graduação em Biologia Animal, Departamento de Zoologia, Universidade Federal de Pernambuco, Recife, Pernambuco, Brazil

Received 17 June 2016. Revision requested 6 September 2016.

Accepted 20 September 2016. First published online 16 February 2017.
}

Supplementary material for this article can be found at https://doi.org/10.1017/So030605316001186

\section{Introduction}

Secies with specific roosting, foraging and/or breeding $\checkmark$ requirements tend to be particularly vulnerable to habitat loss and degradation (e.g. Jones et al., 2003; Cardillo et al., 2005; Davidson et al., 2009). In the case of bats, the availability and environmental condition of caves can be a limiting factor for several species (Glover \& Altringham, 2008), and the conservation of caves is frequently highlighted as being a priority for bats (Arita, 1996; Goodman et al., 2005; Kingston, 2010; Bernard et al., 2012).

Endemic to the Neotropics, species of the family Natalidae are considered to be cave specialists (Tejedor, 2011). These insectivorous bats have funnel-shaped ears, and their tails are usually longer than their total body length (Gardner, 2008; Tejedor, 2011). All males have a natalid organ, located on the dorsal surface of the muzzle, which secretes a substance that can facilitate intraspecific communication (Tejedor, 2011). Bats of this family are light (2-12 g) and small (forearm length 26-51 mm; Tejedor, 2011). Currently, there are three extant recognized genera in the family: Chilonatalus, Natalus and Nyctiellus (Morgan \& Czaplewski, 2003; Tejedor, 2011; Nogueira et al., 2014).

Eight species of Natalus are known: N. jamaicensis, $N$. lanatus, $N$. macrourus, $N$. major, $N$. mexicanus, $N$. primus, $N$. stramineus and N. tumidirostris (Tejedor, 2011). In South America, south of the Amazon River, only the species N. macrourus (formerly known as N. espiritosantensis) is known to occur, in Bolivia, Brazil and Paraguay (Tejedor, 2011; Garbino \& Tejedor, 2012). Natalus macrourus is categorized as Near Threatened on the IUCN Red List (Tejedor \& Davalos, 2016) but it is one of the six bat species officially designated as threatened in Brazil, where it is categorized as Vulnerable on the basis of a projected population reduction associated with a decline in its area of occupancy, extent of occurrence and/or quality of habitat (criterion $\mathrm{A}_{3} \mathrm{c}$; MMA, 2014). Although N. macrourus has a larger distribution than other congeneric species, records are rare within its range (Tejedor, 2011), and there is still a paucity of knowledge about its biology, ecology and natural history.

In this study we (1) addressed gaps in the known distribution of N. macrourus in Brazil, obtaining new records for 
the north-eastern region, (2) updated data on the distribution of the species in Brazil, (3) used these data together with climate and environmental modelling to generate a refined map of the potential distribution of the species in Brazil, (4) analysed pressures on and threats to the species, and (5) assessed its conservation needs.

\section{Methods}

\section{Current and potential distribution}

We reviewed the available records of $N$. macrourus in Brazil by searching the scientific literature for the key words Natalus and Natalidae in Web of Science (2015) and Google Scholar (2015). In addition, we searched for records in the databases of the Chico Mendes Institute for Biodiversity Conservation (ICMBio, 2016), speciesLink (2015), VertNet (2015) and the Global Biodiversity Information Facility (GBIF, 2015; Supplementary Table S1).

The records obtained from the literature were converted into points of occurrence and used to model the potential distribution of $N$. macrourus in Brazil (Supplementary Table $S_{1}$ ). Each record was checked and filtered for mistakes in location and/or taxonomy (Peterson et al., 2011). Points that are too close and under the same environmental conditions can bias the modelling as a result of so-called spatial autocorrelation (Boria et al., 2014). To reduce the inherent geographical biases associated with collection data and avoid spatial autocorrelation problems, we produced a map of environmental heterogeneity, using the bioclimatic variables available from WorldClim (2015), and removed records that were within $25 \mathrm{~km}$ of one another under the same environmental conditions, keeping the maximum possible number of localities. This resulted in 50 single localities.

Using MaxEnt (Phillips et al., 2006), we generated various distribution models for N. macrourus, based on two sets of variables at $1 \mathrm{~km}^{2}$ resolution. To avoid collinearity among bioclimatic variables (i.e. when two variables are highly correlated) we calculated Pearson correlations for the 22 variables available in the WorldClim database and, for those with $\geq 80 \%$ correlation, eliminated the one with the lowest contribution. Following this selection, for the first set of variables we considered nine bioclimatic variables derived from temperature and rainfall (mean daily temperature range, isothermality, temperature seasonality, maximum temperature in the warmest month, mean temperature in the wettest quarter, mean temperature in the coldest quarter, annual rainfall, rainfall in the driest quarter, rainfall in the warmest quarter). In the second set we considered the same nine bioclimatic variables plus altitude, the normalized difference vegetation index (a proxy for measuring vegetation cover) and a categorical variable of the potential occurrence of caves in Brazil, produced by the National
Centre for Cave Research. The shapefile for the potential occurrence of caves in Brazil was produced using data on the location of the main karst regions of Brazil, the geological map of the country, georeferenced records of caves in the database of the National Centre for Cave Research, and the main lithological formations of the caves. We used this approach because N. macrourus is generally regarded as a cave-dwelling species (Tejedor \& Davalos, 2016). Considering that only a small fraction of Brazilian caves are known, we adopted potential occurrence as a proxy for cave existence in a given area. The National Centre for Cave Research categorizes the potential of cave occurrence in Brazil as unlikely, low, medium, high and very high. In our analysis we scored these categories $0-4$, and used the scores to refine the modelling of the potential distribution of N. macrourus.

We conducted various tests to find the best parametrization for MaxEnt (Radosavljevic \& Anderson, 2014). We set the program to use $80 \%$ of the data to calibrate the model and $20 \%$ for the test, using $n-1$ replicates, where $n$ is the number of records of occurrence, as suggested by Pearson et al. (2007). To assess the predictive capacity of the models we used the area under the curve (AUC); the best-performing models had AUC values close to 1, whereas AUC values close to 0.5 indicated models were equal to or worse than random (Phillips \& Dudík, 2008).

\section{Conservation scenarios for the species}

To mitigate the occurrence of false positives (commission errors), the potential distribution generated included a buffer of $300 \mathrm{~km}$ around the minimum convex polygon produced with known points of occurrence. Considering the minimum training presence threshold (i.e. the lowest predicted value associated with any one of the observed presence records; Peterson et al., 2011; Radosavljevic \& Anderson, 2014), our analysis indicated $18 \%$ as the threshold for the presence of Natalus. Therefore, we categorized the potential distribution according to occurrence probability: very low $(<18 \%)$, low (18-25\%), medium (26-50\%), high (51-75\%) and very high $(>$ $75 \%)$. We overlapped the potential distribution generated with three other datasets: (1) deforested areas in Brazil until 2009 (SISCOM, 2015), (2) potential occurrence of caves (CECAV, 2015), and (3) boundaries of fully protected areas as of 2011 (MMA, 2016). This overlap facilitated the calculation of the area of occupation of the species, the number of potential roosts within that area, and the occurrence distribution within protected areas. We also calculated the percentage of caves within the range of the species in habitat remnants for the entire country and for the north-eastern region, and the percentage of caves potentially under pressure from mining activities (DNPM, 2015) and wind farms (ANEEL, 2015). 


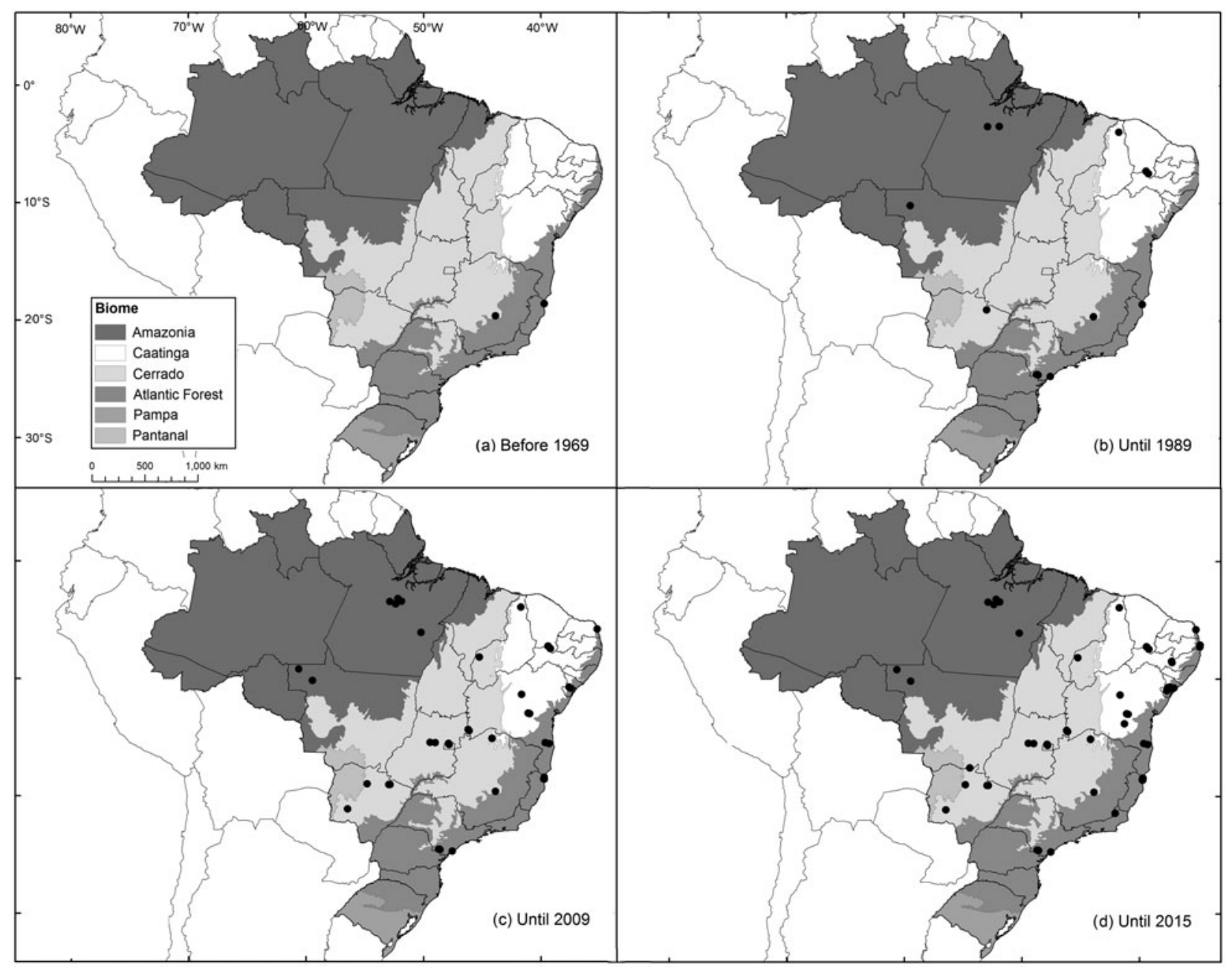

FIG. 1 Spatial evolution of records of the Brazilian funnel-eared bat Natalus macrourus (Natalidae) from 1893 to 2015.

\section{Results}

\section{Known and new records}

Our literature survey yielded 81 records of $N$. macrourus in Brazil (Fig. 1; Supplementary Table S1). We added new records for the north-eastern state of Pernambuco, obtained from captures made during a bat inventory in the cave Meu Rei in Catimbau National Park $(62,292 \mathrm{ha})$, which is located within the Caatinga biome (ICMBio, 2015). The cave is within a sandstone formation, with a horizontal length of $162 \mathrm{~m}$ (Azevedo \& Bernard, 2015). It harbours a bat community that includes at least seven other species of two families (Phyllostomidae: Diphylla ecaudata, Carollia perspicillata, Glossophaga soricina, Anoura geoffroyi, Lonchorhina aurita, Tonatia bidens; and Mormoopidae: Pteronotus gymnonotus), which at certain times can surpass 120,000 individuals, most of them P. gymnonotus. Measurements in two chambers of the cave, one in its central part and the other in a deeper part, yielded mean temperatures of 25 and $28^{\circ} \mathrm{C}$, and relative humidity of 80 and $87 \%$, respectively. The cave is a high priority for full protection (Azevedo \& Bernard, 2015).
Using hand nets we captured eight $N$. macrourus (4 males and 4 females) in the cave Meu Rei. The captures were made in October and December 2014, and March, May, June, August and October 2015. Three of these individuals were collected; the others were not marked, so recaptures were possible. We weighed and measured each bat and estimated its age and reproductive status, but retained only the first individual as a voucher, which we deposited in the Mammal Collection of the Federal University of Pernambuco (UFPE 3317; ICMBio/MMA permit \#43816-1; Ethics Committee on Animal Care-UFPE \#23076.027916/ 2015-13). All the other bats were released at the site of capture. We recorded another individual of $N$. macrourus on 14 May 2015 during a visit to another cave $11 \mathrm{~km}$ away, outside the limits of Catimbau National Park.

The records from Pernambuco were added to the existing records of the species in Brazil for $1893^{-2015}$ (Fig. 2). Sixty percent of these records are from caves, grottos or within $5 \mathrm{~km}$ of known caves, and $70 \%$ are from within $10 \mathrm{~km}$ of known caves. Thirty percent of all records are from ecotones between savannah, steppic savanna, dry coastal vegetation 


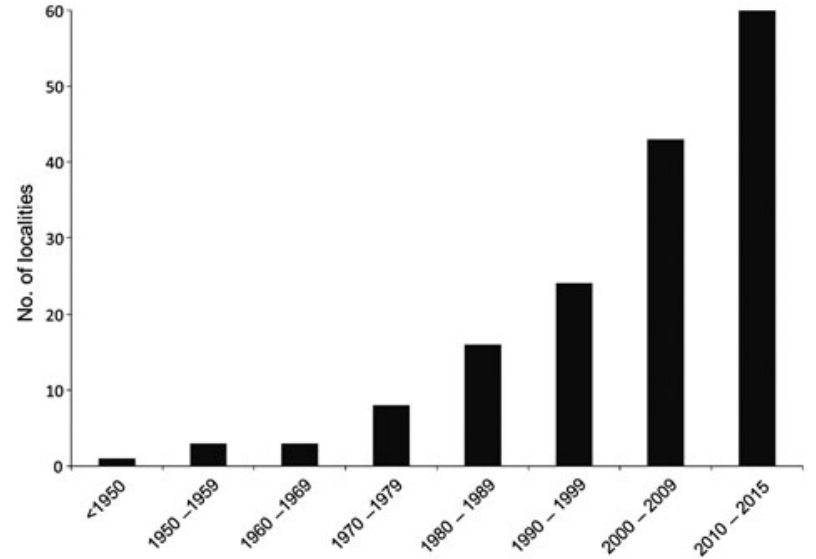

FIG. 2 Temporal evolution of the number of localities with known records of the Brazilian funnel-eared bat in Brazil from 1893 to 2015.

(restinga), or croplands, $25 \%$ are from dense rainforests, and $20 \%$ are from savannahs. The records are broadly distributed and occupy four of the six Brazilian biomes (Fig. 1). Most records are from Atlantic Forest (40\%), followed by Cerrado (23\%), Amazonia (17\%) and Caatinga (16\%). In 2015 N. macrourus was included in the species list for the Pantanal, based on records in the state of Mato Grosso do Sul (Fischer et al., 2015).

\section{Potential distribution modelling}

The potential distribution of $N$. macrourus modelled using bioclimatic variables combined with the potential occurrence of caves was $4,445,996 \mathrm{~km}^{2}\left(\mathrm{AUC}_{\text {training }}=0.89 \pm \mathrm{SD}\right.$ 0.01; $\mathrm{AUC}_{\text {test }}=0.87 \pm \mathrm{SD} 0.05$ ), which is $11.5 \%$ smaller than the potential distribution modelled using bioclimatic variables only, which was $5,024,815 \mathrm{~km}^{2}\left(\mathrm{AUC}_{\text {training }}=0.86 \pm \mathrm{SD}\right.$ 0.01; $\mathrm{AUC}_{\text {test }}=0.85 \pm \mathrm{SD}$ 0.04). However, considering the potential distribution based on both bioclimatic variables and the potential occurrence of caves there was a reduction of $26 \%$ in the areas of highest environmental suitability $(>75 \%)$ for the species when compared with the model based on bioclimatic variables only. Our model suggests that N. macrourus is positively associated with areas where there is a high potential occurrence of caves, and negatively associated with areas with high variation in mean daily temperature and mean annual rainfall.

The areas of highest environmental suitability for $N$. macrourus corresponded to only $3 \%$ of the total area of potential distribution, and these areas were within the Caatinga and Atlantic Forest biomes, mostly in the northeastern region. That region alone comprised $67 \%$ of the total area of highest environmental suitability in the model that included the potential occurrence of caves, and 92\% in the model with bioclimatic variables alone (Fig. 3). In the Atlantic Forest, the areas of highest environmental suitability were located in Sergipe, Alagoas, eastern Bahia, and mid-eastern Pernambuco and Paraíba states. Additionally, the areas of high environmental suitability (50-75\%) accounted for $<20 \%$ of the total area modelled, and were located mostly in the Atlantic Forest of northeastern Brazil $55 \%$ in the model including the potential cave occurrence variable; $46 \%$ without). Areas of low environmental suitability (18-25\%) were found in north-western Bahia, southern Piauí and eastern Amazonas (to the south of the Amazon River) states, as well as in mid-northern Mato Grosso, Tocantins and Paraná states.

\section{Conservation scenarios for the species}

Based on the model of potential distribution of the species, considering the importance of caves for $N$. macrourus and considering the area where original vegetation cover was already lost, we estimate that the species has already lost 54\% of its habitat in Brazil and that there are $<35 \%$ of habitat remnants in areas with the highest environmental suitability (Fig. 3). We estimate that $53 \%$ of the caves recorded within the distribution of $N$. macrourus are in habitat remnants and c. $54 \%$ are $<5 \mathrm{~km}$ from mining operations. Furthermore, $2 \%$ of these caves are $<10 \mathrm{~km}$ from wind farms, and only $4 \%$ of the potential distribution of $N$. macrourus is located within fully protected areas.

Approximately $30 \%$ of the area of potential distribution of $N$. macrourus is located in north-eastern Brazil, where $44 \%$ of the caves are in human-modified areas. We estimate that N. macrourus has already lost $50 \%$ of its natural habitat in north-eastern Brazil, and up to $65 \%$ in areas of highest environmental suitability in the eastern part of the region, where human population growth is higher. In that region only $2 \%$ of the potential distribution of N. macrourus is located within fully protected areas.

\section{Discussion}

The records of $N$. macrourus indicate a broad distribution in Brazil, with the species occurring from xeric (e.g. the Caatinga, with annual rainfall $<800 \mathrm{~mm}$ ) to moist habitats (e.g. the Amazon, with annual rainfall $>2,000 \mathrm{~mm}$; Tejedor, 2011). However, although our model suggests a large potential distribution, most of the records in Brazil are from areas of open vegetation, and our models suggest a preference for areas with low mean annual rainfall, lower variation in daily temperature, and high cave occurrence potential. These preferences may significantly restrict the effective area of occurrence of $N$. macrourus. We observed that only $3 \%$ of the total area of potential distribution has high environmental suitability for the species, and is located in the Caatinga and Atlantic Forest, mostly in north-eastern Brazil. 


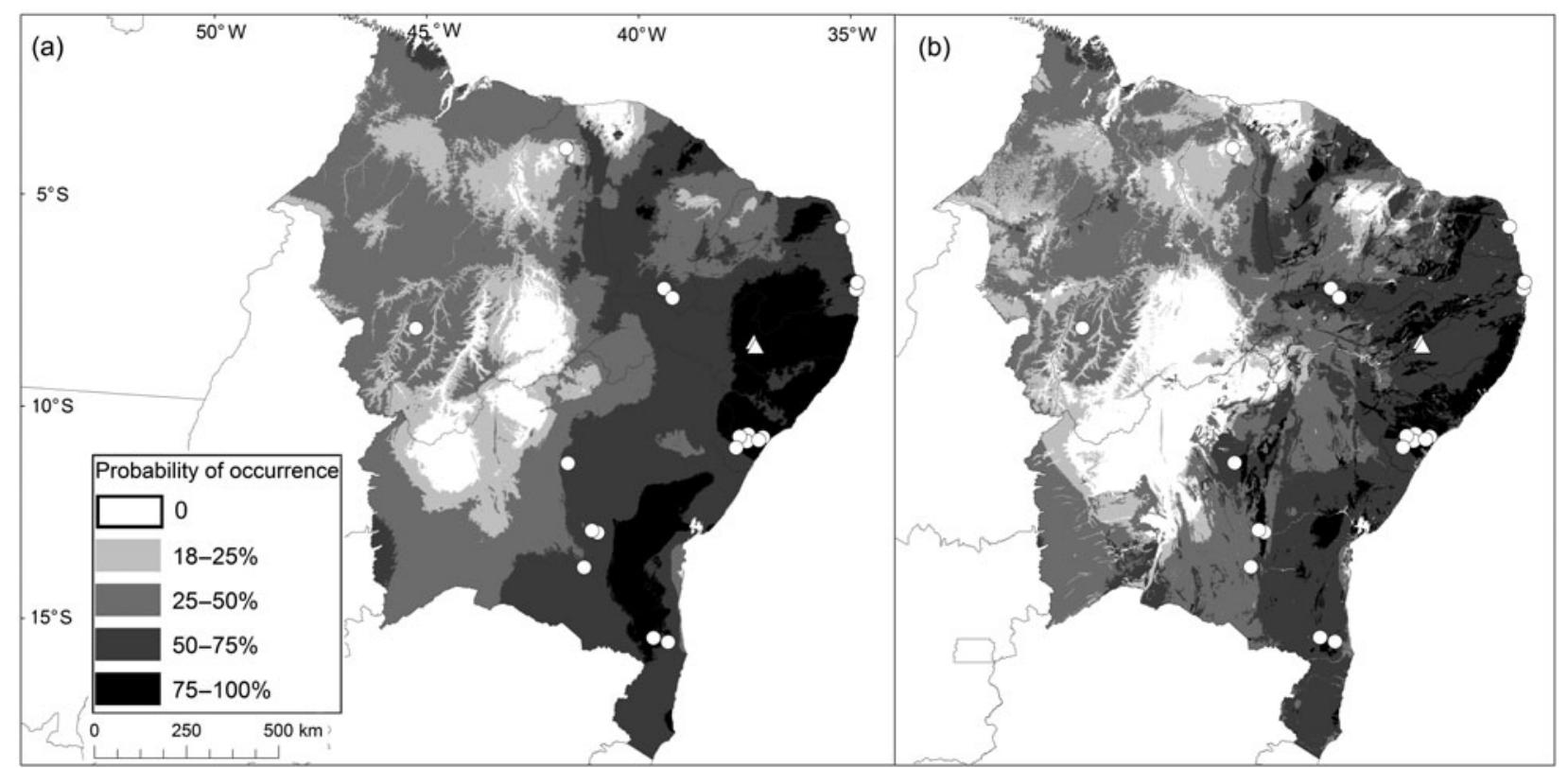

FIG. 3 Potential distribution of the funnel-eared bat N. macrourus in north-eastern Brazil, modelled considering only bioclimatic variables (a), and with the addition of cave occurrence potential (b). White circles represent known records for the species, and white triangles represent new records for the state of Pernambuco.

Brazil may have $>310,000$ caves (Piló \& Auler, 2011) but $<5 \%$ of them have been officially recorded (ICMBio/ CECAV, 2016). Species of the genus Natalus are considered to be dependent on caves for roosting (Taddei \& Uieda, 2001; Tejedor et al., 2004; Tejedor \& Davalos, 2016), and our analysis confirms this strong association. This finding is a cause for concern, as changes in the Brazilian cave protection law have increased the vulnerability of cave environments and may result in a poor outlook for the conservation of cave-dependent species. Until 2008, Brazilian caves were fully protected. However, the law was changed by Presidential Decree no. 6,640, which determined that caves should be categorized according to their relevance, and only those categorized as being of 'maximum relevance' would be fully protected (Brasil, 2008). The prior categorization of all the Brazilian caves as a prerogative for their protection is infeasible and, in practice, the change in the law has reduced their protection, as caves in the categories of high, medium and low relevance may be legally exploited and destroyed. Decree no. 6,640 is therefore considered to be a serious threat to the conservation of Brazilian bats (Bernard et al., 2012). Cave protection is highlighted as being a priority for bat conservation (e.g. Fenton, 1997; Luo et al., 2013; Furey \& Racey, 2016) and an increase in the number of formally protected roosts is needed urgently in Brazil, given the pressure on cave environments there (e.g. Ribeiro, 2015).

As well as depending on caves for shelter, Natalus bats, which are strictly insectivorous, also depend on having tracts of habitat of sufficient environmental quality available for foraging. Therefore, N. macrourus may face other pressures in addition to roost loss. Our results suggest that c. $54 \%$ of the known caves within the potential distribution of $N$. macrourus are $<5 \mathrm{~km}$ from mining areas. Besides the direct loss of shelters caused by the exploration of caves for mining, explosives frequently used in that process, the presence of people, and the noise caused by machinery can affect bats using these shelters (Furey \& Racey, 2016). Furthermore, $2 \%$ of these caves are $<10 \mathrm{~km}$ from wind farms, which are another threat to bats (Barclay et al., 2007; Arnett et al., 2008). The catchment areas of wind farms in the Neotropics are largely unknown but studies in Europe and Canada have found that wind turbines influence not only bat populations in close proximity but also those at distances of several hundreds of kilometers or even $>1,000 \mathrm{~km}$ (Voigt et al., 2012; Baerwald et al., 2014). We recommend that caves with confirmed occurrence of $N$. macrourus close to mines or wind farms should be protected and monitored in the medium and long term.

The conservation outlook for N. macrourus would be more positive if there were a larger number of protected areas within its distribution. However, only $4 \%$ of the potential distribution of N. macrourus is located within fully protected areas. In the north-eastern region, which has the greatest potential occurrence of $N$. macrourus, the percentage is even lower $(2 \%)$. Hence, a scenario in which low roost protection is combined with other threats, such as mining and habitat loss, degradation and fragmentation, could extitrpate some populations locally (Tejedor, 2011).

Natalus spp. are frequently associated with several other bat species (Ruschi, 1951; Trajano \& Moreira, 1991; Trajano \& Gimenez, 1998; Gregorin \& Mendes, 1999; Taddei \& 
Uieda, 2001). We observed $N$. macrourus roosting with A. geoffroyi, C. perspicillata, D. ecaudata, G. soricina, L. aurita, P. gymnonotus and T. bidens; L. aurita is also categorized as Vulnerable in Brazil. Hence, protecting the caves used by $N$. macrourus could also conserve other species of bats as well as the rich, highly specialized and frequently endemic cave biota (Furey \& Racey, 2016).

Robust databases of species records are necessary for improving potential distribution models in large and undersampled countries, such as Brazil (e.g. Oliveira et al., 2016), which would, in turn, highlight priority areas for inventories and conservation (Costa et al., 2010; Moreira et al., 2014; Ingberman et al., 2016). However, species distribution models are influenced by many factors, such as spatial resolution, environmental variables and the quality of distribution records. The addition of new records can produce distinct modelling outputs, and models based on partial datasets for species occurrence can lead conservationists or decision makers to incorrect conclusions (Aguiar et al., 2016).

There are no formal records of bats for almost $60 \%$ of Brazil (Bernard et al., 2011) and there is limited knowledge of the distribution of several bat species in the country. New records, such as those reported here from Pernambuco, help to reduce these gaps for poorly known, hard to capture species, such as Natalus spp. The previous records closest to Pernambuco were from Ceará, Sergipe and Paraíba states, $>235 \mathrm{~km}$ from our study area (Taddei \& Uieda, 2001; Rocha et al., 2013). Moreover, nearly half of the 81 records of occurrence of N. macrourus in Brazil have been gathered since 2000 (Fig. 1; Leal et al., 2012), indicating that recent efforts have resulted in a significant refinement of the species' distribution. Considering the high potential occurrence of caves in north-eastern Brazil (Jansen et al., 2012), and considering that at least three (N. macrourus, L. aurita and Furipterus horrens) of the six threatened bat species in Brazil are frequent or exclusive cave users, caves in northeastern Brazil are a priority for bat inventories so that roosts used by Natalus or any other threatened bat species can be identified and proposed for full protection.

\section{Acknowledgements}

We thank Ana Claudia Jardelino, Evelyn Figueiredo, Frederico Hintze, Jaire Torres and Ítalo Azevedo for their help with field work, and Project Ecológico de Longa Duração Sítio Parque Nacional do Catimbau for logistical support. We thank Valéria Tavares for sharing information on records of N. macrourus. Coordenação de Aperfeicoamento de Pessoal de Nível Superior granted scholarships to M. Delgado-Jaramillo and E. Barbier, and Conselho Nacional de Desenvolvimento Científico e Tecnológico granted a fellowship to E. Bernard. The study was funded by Fundação Grupo Boticário de Proteção à Natureza (process \#0983-20132). We thank Departamento de Zoologia, Centro de Ciências Biológicas da Universidade Federal de Pernambuco for supporting our studies on bats in Brazil. We thank two anonymous reviewers for their constructive comments.

\section{Author contributions}

M. Delgado-Jaramillo collected data and conducted the analysis. E. BARBIER collected data. E. BERNARD conceived the research. All authors contributed to writing the article.

\section{References}

Aguiar, L.M.S., Bernard, E., Ribeiro, V., Machado, R. B. \& Jones, G. (2016) Should I stay or should I go? Climate change effects on the future of Neotropical savannah bats. Global Ecology and

Conservation, 5, 22-33.

ANEel (Agência Nacional de Energia Elétrica) (2015) Http:// sigel.aneel.gov.br/portal/home/index.html [accessed 13 December 2016].

Arita, H.T. (1996) The conservation of cave-roosting bats in Yucatan, Mexico. Biological Conservation, 76, 177-185.

Arnett, E.B., Brown, W.K., Erickson, W.P., Fiedler, J.K., Hamilton, B.L., Henry, T.H. et al. (2008) Patterns of bat fatalities at wind energy facilities in North America. The Journal of Wildlife Management, 72, 61-78.

Azevedo, I.S. \& Bernard, E. (2015) Avaliação do nível de relevância e estado de conservação da caverna "Meu Rei" no PARNA Catimbau, Pernambuco. Revista Brasileira de Espeleologia, 1, 1-23.

Baerwald, E.F., Patterson, W.P. \& Barclay, R.M.R. (2014) Origins and migratory patterns of bats killed by wind turbines in southern Alberta: evidence from stable isotopes. Ecosphere, 5, 1-17.

Barclay, R.M.R., BAERWALD, E.F. \& Gruver, J.C. (2007) Variation in bat and bird fatalities at wind energy facilities: assessing the effects of rotor size and tower height. Canadian Journal of Zoology, 85, 381-387.

Bernard, E., Aguiar, L.M.S., Brito, D., Cruz-Neto, A.P., Gregorin, R., Machado, R.B. et al. (2012) Uma análise de horizontes sobre a conservação de morcegos no Brasil. In Mamíferos do Brasil: genética, sistemática, ecologia e conservação, Volume II (eds T.R.O. Freitas \& E.M. Vieira), pp. 19-35. Sociedade Brasileira de Mastozoologia, Rio de Janeiro, Brazil.

Bernard, E., Aguiar, L.M.S. \& Machado, R.B. (2011) Discovering the Brazilian bat fauna: a task for two centuries? Mammal Review, 41, 23-39.

Bordignon, M.O. (2006) Diversidade de morcegos (Mammalia, Chiroptera) do Complexo Aporé-Sucuriú, Mato Grosso do Sul, Brasil. Revista Brasileira de Zoologia, 23, 1002-1009.

Boria, R.A., Olson, L.E., Goodman, S.M. \& Anderson, R.P. (2014) Spatial filtering to reduce sampling bias can improve the performance of ecological niche models. Ecological Modelling, 275, 73-77.

Brasil (2008) Decreto $n^{\circ}$ 6.640, de 7 de novembro de 2008. Http:// www.planalto.gov.br/ccivil_03/_Ato2007-2010/2008/Decreto/ D6640.htm [accessed 26 April 2015].

Cardillo, M., Mace, G.M., Jones, K.E., Bielby, J., Bininda-Emonds, O.R.P., Sechrest, W. et al. (2005) Multiple causes of high extinction risk in large mammal species. Science, 309, 1239-1241. 
CeCaV (Centro Nacional de Pesquisa e Conservação de CAVERnas) (2015) Http://www.icmbio.gov.br/cecav/projetose-atividades/potencialidade-de-ocorrencia-de-cavernas.html [accessed 26 April 2015].

Costa, G.C., Nogueira, C., Machado, R.B. \& Colli, G.R. (2010) Sampling bias and the use of ecological niche modeling in conservation planning: a field evaluation in a biodiversity hotspot. Biodiversity and Conservation, 19, 883-899.

Cunha, N.L., Fischer, E. \& S Antos, C.F. (2011) Bat assemblage in savanna remnants of Sonora, central-western Brazil. Biota Neotropica, 11, 197-201.

Davidson, A.D., Hamilton, M.J., Boyer, A.G., Brown, J.H. \& Ceballos, G. (2009) Multiple ecological pathways to extinction in mammals. Proceedings of the National Academy of Sciences of the United States of America, 106, 10702-10705.

DNPM (Departamento Nacional de Produção Mineral) (2015) SIGMINE. Http://www.dnpm.gov.br/assuntos/ ao-minerador/sigmine [accessed 13 December 2016].

Esberard, C.E.L., Baptista, M., Costa, L.M., Luz, J.L. \& Lourenço, E.C. (2010) Morcegos de Paraiso de Tobias, Miracema, Rio de Janeiro. Biota Neotropica, 10, 249-256.

Esberard, C.E.L., Motta, J.A. \& Perigo, C. (2005) Morcegos cavernícolas da Área de Proteção Ambiental (APA) Nascentes do Rio Vermelho, Goiás. Revista Brasileira Zoociências, 7, 311-325.

Faria, D., Soares-Santos, B. \& Sampaio, E. (2006) Bats from the Atlantic rainforest of southern Bahia, Brazil. Biota Neotropica, 6, 1-13.

Feijó, J.A. \& Langguth, A. (2011) Lista de Quirópteros da Paraíba, Brasil com 25 novos registros. Chiroptera Neotropical, 17, 1055-1062.

Fenton, M.B. (1997) Science and the conservation of bats. Journal of Mammalogy, 78, 1-14.

Fischer, E., Santos, C.F., Carvalho, L.F.A.C., Camargo, G., Cunha, N.L., Silveira, M. et al. (2015) Bat fauna of Mato Grosso do Sul, southwestern Brazil. Biota Neotropica, 15, 1-17.

Furey, N.M. \& RACEY, P.A. (2016) Conservation ecology of cave bats. In Bats in the Anthropocene: Conservation of Bats in a Changing World (eds C.C. Voigt \& T. Kingston), pp. 463-50o. Springer, New York, USA.

Garbino, G.S.T. \& Tejedor, A. (2012) Natalus macrourus (Gervais, 1856) (Chiroptera: Natalidae) is a senior synonym of Natalus espiritosantensis (Ruschi, 1951). Mammalia, 77, 237-240.

Gardner, A.L. (2008) Family Natalidae. In Mammals of South America: Marsupials, Xenarthrans, Shrews, and Bats, Volume I (ed. A.L. Gardner), pp. 397-399. The University of Chicago Press, Chicago, USA.

GBif (Global Biodiversity Information Facility) (2015) Http://www.gbif.org/ [accessed 16 April 2015].

Glover, A.M. \& Altringham, J.D. (2008) Cave selection and use by swarming bat species. Biological Conservation, 141, 1493-1504.

Goodman, S.M., Andriafidison, D., Andrianaivoarivelo, R., Cardiff, S.G., Ifticene, E., Jenkins, R.K.B. et al. (2005) The distribution and conservation of bats in the dry regions of Madagascar. Animal Conservation, 8, 153-165.

Google Scholar (2015) Https://scholar.google.com.br [accessed 26 April 2015].

Gregorin, R. \& Mendes, L.F. (1999) Sobre quirópteros (Emballonuridae, Phyllostomidae, Natalidae) de duas cavernas da Chapada Diamantina, Bahia, Brasil. Iheringia Série Zoológica, 86, 121-124.

iCmbio (Instituto Chico Mendes de Conservação da Biodiversidade) (2015) Parna do Catimbau. Http://www.icmbio.gov.br/portal/biodiversidade/unidadesde-conservacao/biomas-brasileiros/caatinga/unidades-deconservacao-caatinga/2135-parna-do-catimbau.html?highlight= WyJjYXRpbWJcdTAw ZTFiIlo= [accessed 26 April 2015]. icmbio (Instituto Chico Mendes de Conservação da Biodiversidade)/CECAV (Centro Nacional de Pesquisa e Conservação de Cavernas (2016) Cadastro Nacional de Informações Espeleológicas - CANIE. Http://www.icmbio.gov.br/ cecav/canie.html [accessed 30 September 2016].

Ingberman, B., Fusco-Costa, R. \& Monteiro-Filho, E.L.A. (2016) A current perspective on the historical geographic distribution of the endangered muriquis (Brachyteles spp.): implications for conservation. PLoS ONE, 11(3), e0150906.

Jansen, D.C., Cavalcanti, L.F. \& Lamblém, H.S. (2012) Mapa de potencialidade de ocorrência de cavernas no Brasil, na escala 1:2.500.00o. Revista Brasileira de Espeleologia, 2, 42-57.

Jones, K.E., Purvis, A. \& Gittleman, J.L. (2003) Biological correlates of extinction risk in bats. The American Naturalist, 161, 601-614.

Kingston, T. (2010) Research priorities for bat conservation in Southeast Asia: a consensus approach. Biodiversity and Conservation, 19, 471-484.

Leal, E.S.B., Ramalho, D.F., Miller, B.G., Filho, P.B.P., Neto, J.G. P., Nova, F.V.P.V. et al. (2012) Primeiro registro da família Natalidae (Mammalia: Chiroptera) para a Caatinga do estado da Paraíba, Nordeste do Brasil. Revista Brasileira Zoociências, 14, 243-253.

Luo, J., Jiang, T., Lu, G., Wang, L., WanG, J. \& FenG, J. (2013) Bat conservation in China: should protection of subterranean habitats be a priority? Oryx, 47, 526-531.

Mares, M.A., Willig, M.R., Streilein, K.E. \& Lacher, T.E. (1981) The mammals of northeastern Brazil: a preliminary assessment. Annals of Carnegie Museum, 50, 81-137.

ma (Ministério do Meio Ambiente) (2014) - Portaria $n^{\circ} 444$ de dezembro de 2014. Diário Oficial da União, Brasília, Brazil.

MMA (Ministério do Meio Ambiente) (2016) Http://mapas.mma. gov.br/izgeo/datadownload.htm [accessed 26 April 2015].

Mok, W.Y., Wilson, D.E., LACEY, L.A. \& LuizÃo, R.C.C. (1982) Lista atualizada da quirópteros da Amazônia Brasileira. Acta Amazonica, $12,817-823$.

Moreira, D.O., Leite, G.R., Siqueira, M.F., Coutinho, B.R., Zanon, M.S. \& Mendes, S.L. (2014) The distributional ecology of the maned sloth: environmental influences on its distribution and gaps in knowledge. PLoS ONE, 9(10), e110929.

Morgan, G.S. \& Czaplewski, N.J. (2003) A new bat (Chiroptera: Natalidae) from the early Miocene of Florida, with comments on natalid phylogeny. Journal of Mammalogy, 84, 729-752.

Nogueira, M.R., Lima, I.P., Moratelli, R., Tavares, V.C., Gregorin, R. \& Peracchi, A.L. (2014) Checklist of Brazilian bats, with comments on original records. Check List, 10, 808-821.

Oliveira, U., Paglia, A.P., Brescovit, A.D., de Carvalho, C.J.B., Silva, D.P., Rezende, D.T. et al. (2016) The strong influence of collection bias on biodiversity knowledge shortfalls of Brazilian terrestrial biodiversity. Diversity and Distributions, 22, 1232-1244.

Pearson, R.G., Raxworthy, C.J., Nakamura, M. \& Peterson, A.T. (2007) Predicting species distributions from small numbers of occurrence records: a test case using cryptic geckos in Madagascar. Journal of Biogeography, 34, 102-117.

Peterson, A.T., Soberón, J., Pearson, R.G., Anderson, R.P., Martínez-Meyer, E., Nakamura, M. \& Araújo, M.B. (2011) Ecological Niches and Geographic Distributions. Princeton University Press, Princeton, USA.

Phillips, S.J., Anderson, R.P. \& Schapire, R.E. (2006) Maximum entropy modeling of species geographic distributions. Ecological Modelling, 190, 231-259.

Phillips, S.J. \& Dudík, M. (2008) Modeling of species distributions with MaxEnt: new extensions and a comprehensive evaluation. Ecography, 31, 161-175. 
Piló, L.B. \& Auler, A. (2011) Introdução à Espeleologia. In III Curso de Espeleologia e Licenciamento Ambiental, pp. 7-23. ICMBio/ CECAV, Brasília, Brazil.

Radosavljevic, A. \& Anderson, R.P. (2014) Making better Maxent models of species distributions: complexity, overfitting and evaluation. Journal of Biogeography, 41, 629-643.

Ribeiro, A.A. (2015) Ameaças à conservação do patrimônio espeleológico em litologias ferríferas. Revista Brasileira de Espeleologia, 1, 24-38.

Rocha, P.A., Mikalauskas, J.S., Bocchiglieri, A., Feijó, J.A. \& FERRARI, S.F. (2013) An update on the distribution of the Brazilian funnel-eared bat, Natalus macrourus (Gervais, 1856) (Mammalia, Chiroptera), with new records from the Brazilian Northeastern. Check List, 9, 675-679.

Ruschi, A. (1951) Morcegos do estado do Espirito Santo. Família Vespertilionidae, chave analítica para os gêneros e espécies representadas no E. Santo. Descrição de Myotis nigricans nigricans e Myotis espiritosantensis n. sp. e algumas observações a seu respeito. Boletim do Museu de Biologia Profesor Mello Leitão, 4 $1-11$.

Sbragia, I.A. \& CARDoso, A. (2008) Quirópterofauna (Mammalia: Chiroptera) cavernícola da Chapada Diamantina, Bahia, Brasil. Chiroptera Neotropical, 14, 360-365.

SISCOM (2015) Http://siscom.ibama.gov.br/monitorabiomas [accessed 26 April 2015].

SPeciesLink (2015) Http://www.splink.org.br [accessed 26 April 2015].

TADDEI, V.A. \& UIEDA, W. (2001) Distribution and morphometrics of Natalus stramineus from South America (Chiroptera, Natalidae). Iheringia Série Zoologica, 91, 123-132.

Tejedor, A. (2011) Systematics of Funnel-Eared Bats (Chiroptera: Natalidae). American Museum of Natural History, New York, USA.

Tejedor, A. \& Davalos, L. (2016) Natalus espiritosantensis. The IUCN Red List of Threatened Species 2016: e.T136448A21983924. Http://www.iucnredlist.org/details/136448/o [accessed 1 December 2016].
Tejedor, A., Silva-Taboada, G. \& Rodríguez-Hernández, D. (2004) Discovery of extant Natalus major (Chiroptera: Natalidae) in Cuba. Mammalian Biology, 69, 153-162.

Trajano, E. (1982) New records of bats from southeastern Brazil. Journal of Mammalogy, 63, 529.

Trajano, E. \& Gimenez, E.A. (1998) Bat community in a cave from eastern Brazil, including a new record of Lionycteris (Phyllostomidae, Glossophaginae). Studies on Neotropical Fauna and Environment, 33, 69-75.

Trajano, E. \& Moreira, J.R.A. (1991) Estudo da fauna de cavernas da Província Espeleológica Arenítica Altamira-Itaituba, Pará. Revista Brasileira de Biologia, 51, 13-29.

VertNet (2015) Http://www.vertnet.org [accessed 26 April 2015].

Voigt, C.C., Popa-Lisseanu, A.G., Niermann, I. \& KramerSCHADT, S. (2012) The catchment area of wind farms for European bats: a plea for international regulations. Biological Conservation, $153,80-86$.

Web of SCIEnCE (2015) Http://www.webofknowledge.com [accessed 26 April 2015].

Willig, M.R. (1983) Composition, Microgeographic Variation, and Sexual Dimorphism in Caatingas and Cerrado Bat Communities from Northeast Brazil. Carnegie Museum of Natural History, Pittsburgh, USA.

Winge, H. (1893) Jordfundne og nulevende Flager-mus (Chiroptera) fra Lagoa Santa, Minas Gerais, Brasilien. Med udsigt over Flagermusenes un-dbyrdes Slaegstkab. E Museo Lundii, 2, 1-92.

WORLDClim (2015) Http://www.worldclim.org/ [accessed 26 April 2015].

\section{Biographical sketches}

Mariana Delgado-Jaramillo is interested in how species distribution modelling can be applied to conservation, and her work has focused on bats. EDER BARBIER's research interests include the biology, ecology and geographical distribution of hosts and parasites. EN RICO BERNARD's research is focused on the ecology and conservation of Brazilian biodiversity, with an emphasis on bats. 